\title{
Sociodrama in Improving Self-Adjustment
}

\author{
Nenden Sulistyanti Putri ${ }^{\mathrm{a}}$, Budi Astuti ${ }^{\mathrm{b}}$ \\ ${ }^{a}$ Pascasarjana Universitas Negeri Yogyakarta \\ ${ }^{\mathrm{b}}$ Pascasarjana Universitas Negeri Yogyakarta \\ e-mail: nendensputri.2017@student.uny.ac.id ${ }^{\mathrm{a}}$
}

\begin{abstract}
This article was written to see how effective it is to improve self-adjustment using group guidance services with sociodrama techniques for grade VIII students at SMP Negeri 1 Yogyakarta. This study used aresearch method quasi-experimental design and used amodel non-equivalent control grouppretest and posttest design by comparing the results of 2 groups of research, namely the experimental group which was given services in the form of sociodrama and the control group which was only given the task for independent discussion. Students involved in this service, respectively, the experimental group and the control group amounted to 9 students. Each meeting uses different materials that are used from the aspects contained in the scale grid that is used to be distributed to students to determine the results of the pretest and posttest. The data analysis technique used in this research was thetest Wilcoxon to determine the effect of sociodrama in service delivery. The results of the research that have been carried out indicate an increase in self-adjustment after being given treatment in the form of sociodrama as seen from the comparison of theresults pretest of 74.11 and posttest of 99.78 . It can be concluded that there is a significant increase in value and sociodrama has an effect on increasing student adjustment.
\end{abstract}

\section{Keywords: Sociodrama, Self-Adjustment, Students}

Abstract: Artikel ini ditulis untuk melihat seberapa efektif meningkatkan penyesuaian diri menggunakan layanan bimbingan kelompok dengan teknik sosiodrama untuk siswa kelas VIII di SMP Negeri 1 Yogyakarta. Penelitian ini menggunakan metode penelitian quasi-experimental design dan menggunakan model non-equivalent control grouppretest dan posttest design dengan membandingkan hasil dari 2 kelompok penelitian yaitu kelompok eksperimen yang diberikan pelayanan berupa drama sosial dan kelompok kontrol yang hanya diberi tugas untuk diskusi mandiri. Siswa yang terlibat dalam pelayanan ini masing-masing kelompok eksperimen dan kelompok kontrol berjumlah 9 siswa. Setiap pertemuan menggunakan materi yang berbeda yang digunakan dari aspekaspek yang terdapat pada skala grid yang digunakan untuk dibagikan kepada siswa untuk mengetahui hasil pretest dan posttest. Teknik analisis data yang digunakan dalam penelitian ini adalah uji Wilcoxon untuk mengetahui pengaruh sosiodrama dalam pemberian layanan. Hasil penelitian yang telah dilakukan menunjukkan adanya peningkatan penyesuaian diri setelah diberikan perlakuan berupa sosiodrama dilihat dari perbandingan hasil pretest 74,11 dan posttest 99,78. Dapat disimpulkan bahwa terdapat peningkatan nilai yang signifikan dan sosiodrama berpengaruh terhadap peningkatan penyesuaian diri siswa.

\section{Kata Kunci: Sosiodrama, Penyesuaian Diri, Siswa}

\section{INTRODUCTION}

Low self-adjustment can have a negative impact on individual behavior which results in the individual being unable to socialize well in the school environment, peers, and in the community in his home environment which is shown by distancing reactions from a crowded place or crowd, does not respond well when interacting with individuals or groups or in organizations and the surrounding community. In line with "self-adjustment is a process of how individuals achieve self-balance in meeting their needs according to the environment" (Sunarto \& Hartono, 2008). It is hoped that individuals in the adjustment process will be able to adjust themselves well so that the individual is able to develop himself properly according to the level of individual development with his age. It is reinforced by that "a good self- 
adjustment process involves three elements, namely (1) motivation (2) attitude towards reality, and (3) archetypes" (Ali \& Asrori, 2004).

Ideally, individuals who are in the early adolescent phase, namely the transitional period from childhood to adulthood which is marked by carrying out their developmental tasks in the form of self-search and changes in ways of thinking to learn and seek experiences so that good self-development can be developed himself to the maximum in accordance with the talents and interests of the individual to achieve the goals he dreams of in adulthood because at this time it determines the individual to shape one's character and attitude.

\section{Self-Adjustment Aspects}

Desmita (Desmita, 2009) states that adjustment has several aspects such as emotional maturity, intellectual maturity,social maturity, and responsibilities. High emoational maturity indicated by maturity in emotional life, stability of the atmosphere of togetherness with others, ability to be relaxed, happy, and express aggravation of something, having attitudes and feelings of abilities and realiteies that exist in onesefl and others. The other hand, intelectual maturity indicated ability to achieve self-insight, ability to understand others in their diversity, able to make decisions idependently, and openness in knowing the surrounding environment. People who are having high social maturity could be involve in social partisipation, willingnes to collaborate with others, leadership ability, tolerance attitude towards fellow humans as social beings, and familiarity with the surrounding environment. Human with high responsibilities indicate by productive attitude in self-development, having flexibility in planning and implementing, altruism attitude, Empathy, social, in Relating to Other People, Individuals Have Awareness of the Importance of Having Ethics in Attitude and Being Honest, Able to Self-Reflect on the Consequences Based on the Value System Contained in Society, and Having the Ability to Be Independent

\section{Factors Affecting the Self Adjustment Process}

Ali \& Asrori (2004: 181-189) argues that the factors that influence a person's adjustment have 5 factors, are body condition that associated by individual physical condition related to, (1) offspring (2) body systems, and (3) physical fitness. Second, personality that have influence, that is (1) the awareness of the individual (2) compiling selfregulation (3) self-manifestation forms, and (4) intelligence. Thirtd, learning process that namely (1) as teaching material (2) experienced (3) training, and (4) provision. Fourth, environtment which is related to human resources (HR) that are around human life that can affect growth and development during the process of human life. Fifth, religion and culture which is religion is a teaching, value, and system that governs human life. While culture, one of which is formed from religion and habits carried out by the community and these habits have developed from ancient times. So that religion and culture have a strong enough influence on individual adjustment.

The success of an individual in adapting himself is influenced by several factors such as parenting styles, changes in the school environment, changes in thinking from class VII to class VIII, which are required to be more mature in attitude and speech, peers. These factors can hinder or support an individual in the adjustment process. Students can be categorized as successful, namely the individual is able to process the obstacles that occur into a spirit to change for the better as an individual who is in process (Ghufron \& Rini Risnawati S, 2010). Characteristics of students that arise due to the absence of a good self-adjustment process are generating negative emotions and behavior (Fatimah, 2006).

Based on the problems that arise from the obstacles in the adjustment process which are low and not optimal, the researcher wants to help and provide understanding to students in solving their problems by providing services in the form of group guidance using 
sociodrama techniques. The goal is for students to understand better by practicing a role and interpreting the message to be conveyed through the sociodrama. It is hoped that students will be able to get new knowledge, understanding, application after playing a role where each role has its own meaning. Sociodrama is a service provided to students by means of role playing, where each student plays a role to convey messages and meanings in the material to be delivered. Strengthened by role playing is one of the games used to help students in the social field (Romlah, 2006).

\section{Sociodrama Stages}

The sociodrama game stages (Romlah, 2006) are preparation, creating a script, choosing respondent, choosing audience, preparing group of player, conduct evaluation and discussion, and repeating the game. The preparation made by the facilitator is to provide a brief explanation to the respondent about the problems and themes to be used. As well as telling what roles the respondent plays. Second, creating a script that fits a predetermined theme. Third, choose which respondent is suitable to play a role according to the prepared script. Fourth, forming groups as audience groups. Fifth, the Falisitator gives the group of players time to prepare before starting the activity. Sixth, conduct evaluation and discussion about the sociodrama that has been shown. This evaluation is carried out by the audience group. Then a discussion was held to respond to the evaluation that had been carried out. Last, repeating the game is done when needed.

Sociodrama is considered quite effective because in delivering material, students are invited to play a role in understanding the meaning contained or the message contained in the title of the drama being played, students are helped in solving problems and finding solutions to the problems they are facing. Furthermore, it can help them become more interested and engaged, not only learning about the material, but also learning to integrate knowledge into action, by solving problems, exploring alternatives, and finding new and creative solutions. Sociodrama is one of the best ways to develop one's skills, good cooperation between players, build effective communication, and find solutions to problems. (Blatner, 2000).

Based on the description above, this study aims to see the effect of sociodrama in increasing the adjustment of students in grade VIII. Researchers have done a pretest in class VIII, 9 students were selected to be given treatment in the form of sociodrama with each meeting playing a different role in the material that will be played by the students. Theresults pretest showed low self-adjustment. Therefore, the researcher hopes that by holding a sociodrama, students will experience an increase in the results of the posttest that will be carried out.

Researchers obtained data by means of observation by entering class VIII and interviewing several grade VIII students. It shows the results that students have not been able to adapt themselves well, which is shown by some students who are not able to mingle with their classmates, even many students do not recognize their friends between classes. Students only know their classmates and extracurricular friends. This phenomenon is due to the lack of inter-class activities apart from getting to know friends from extracurricular activities, lack of mingling, lack of interest in recognizing peers, never leaving the house to play with neighbors of the same age. This is due to the tight schedule of their studies both at school and at home, the students come home from school in the afternoon, and in the evening until evening and on weekends they work on assignments from school given by their respective teachers. In fact, it's rare to spend time with family on weekends because of their busy study schedule. These students feel pressured because of demands from the school that require them to get maximum grades because the school is included in the favorite school which requires its students to get good grades. 


\section{METHODS}

The subjects in this study were students of class VIII. The research method used was a quasi experimental design and used amodel non-equivalent control grouppretest and posttest design by comparing the results of the study with 2 groups, namely the experimental group and the control group. The group that will be given treatment is only the experimental group in the form of treatment sociodrama, while in the control group it is not given a treatment like the experimental group, it's just that the control group is only given the task to discuss independently with their group friends with the same material as the experimental group. Determining the sample to be included in this sociodrama by giving a pretest in the form of distributing a self-adjustment scale with the number of items 31 statements with answer choices that are very suitable, appropriate, inappropriate, and very inappropriate. Then, the researcher calculated and analyzed that the students who joined in this study were 9 students in each group. Calculations using thetest Wilcoxon to determine the influence of sociodrama in increasing self-adjustment.

\section{Hypothesis}

The hypothesis of this study is that there is an effect of sociodrama services in increasing the adjustment of class VIII students.

\section{FINDINGS AND DISCUSSION Findings}

Based on the research hypothesis, namely sociodrama in increasing self-adjustment to class VIII students, have been carried out pretest and posttest to see the difference in results from before being given thetreatment and after giving treatment to class VIII students, the researcher will describe the results of thetest Wilcoxon on the adjustment of class VIII students. described as follows:

Table 1 data score pre-test and post-test self adjusment

\begin{tabular}{|c|l|r|c|r|c|}
\hline No & Name & Pre-test & Category & Post-test & Category \\
\hline 1 & AS & 70 & Moderate & 106 & High \\
\hline 2 & CA & 52 & Low & 77 & Moderate \\
\hline 3 & DF & 82 & Moderate & 100 & High \\
\hline 4 & FP & 92 & High & 108 & High \\
\hline 5 & JN & 67 & Moderate & 95 & High \\
\hline 6 & LZ & 107 & High & 112 & High \\
\hline 7 & NY & 60 & Low & 82 & Moderate \\
\hline 8 & YR & 73 & Moderate & 116 & High \\
\hline 9 & YP & 64 & Moderate & 102 & High \\
\hline
\end{tabular}


Based on the table above, the increase in the score will be illustrated in the following chart:

Picture 1. result pretest dan posttest self adjustment

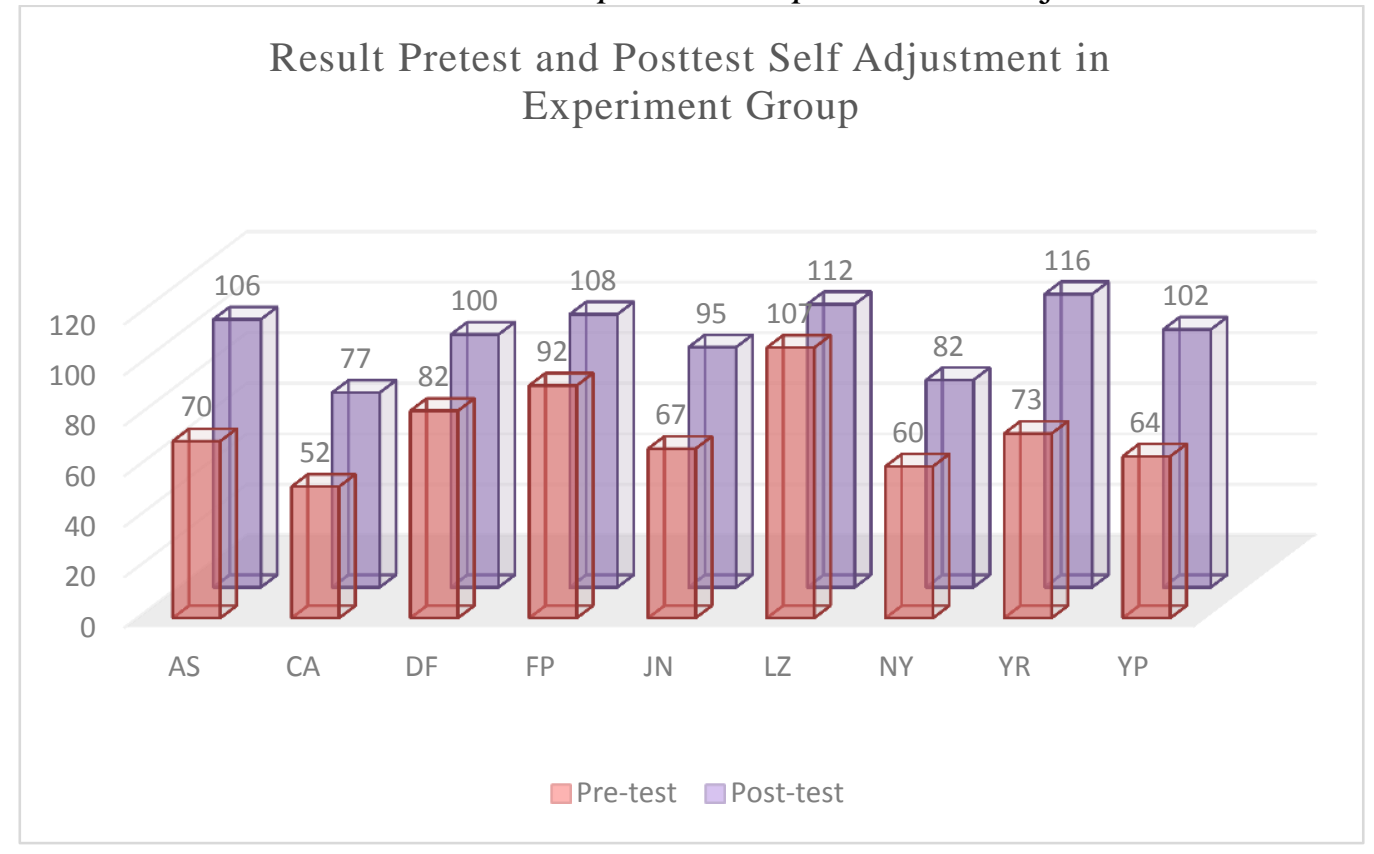

Based on table 1 and Figure 1 above, it can be concluded that the change between the pretest and posttest seen from the 9 grade VIII students experienced an increase in scores. As it is known that the results of the pretest were 2 students got the low category, 5 students got the medium category, and 2 students got the high category. Furthermore, from the scores and categories the researcher gave a treatment in the form of sociodrama as an effort to increase the scores of these students so that there could be an increase in student adjustment. After thegiven treatment was, it can be seen that there was a significant increase in score, namely 7 students experienced an increase in their score and turned into a high category while the other 2 students experienced an increase in their score which was not high enough but there were changes. It can be concluded that students' adjustment has increased after being given treatment.

After the comparison of the results of thescores pretest and posttest above, the researcher calculated using data analysis techniques in the form of thetest Wilcoxon to see the results of the comparison between thescores pretest and posttest, the details are as follows:

Table 2 result Wilcoxon test self adjusment

\begin{tabular}{|lr|}
\hline \multicolumn{3}{|c|}{ Test Statistics $^{\mathrm{a}}$} \\
\hline \multicolumn{3}{|c|}{ Posttest $^{-}$Pretest } \\
Z & $-2.666^{\mathrm{b}}$ \\
$\begin{array}{l}\text { Asymp. Sig. } \\
\text { tailed) }\end{array}$ &, 008 \\
\hline $\begin{array}{l}\text { a. Wilcoxon Signed Ranks Test } \\
\text { b. Based on negative ranks. }\end{array}$ & \\
\hline
\end{tabular}


Table 3 data analysis pretest and posttest

\begin{tabular}{|l|r|r|r|r|r|}
\hline \multicolumn{7}{|c|}{ Descriptive Statistics } \\
\hline & $\mathrm{N}$ & \multicolumn{1}{|c|}{ Mean } & $\begin{array}{c}\text { Std. } \\
\text { Deviation }\end{array}$ & Minimum & Maximum \\
\hline Pretest & 9 & 74,11 & 17,040 & 52 & 107 \\
\hline Posttest & 9 & 99,78 & 13,141 & 77 & 116 \\
\hline
\end{tabular}

Based on the table $2 \& 3$ above, the result shows that there is a difference in results between the pretest and posttest. The difference in these results experienced a significant increase in the pretest, namely before giving treatments sociodrama and, posttest namely after giving treatment sociodramato students. It can be concluded that the answered research hypothesis is indicated by sociodrama having an effect on increasing the adjustment of class VIII students.

\section{Discussion}

This study was intended to determine the effect of sociodrama on the improvement of the eighth grade students' adjustment. In general, the results of the study show that there is a sociodrama effect on the improvement of the eighth grade students' adjustment, these results indicate that the increase in the score has increased significantly. The provision of sociodrama researchers used group guidance services because it was quite effective when providing material because the conditions were conducive and there were not many students who took part in the service, students could freely express their opinions, discussions about the meaning of messages conveyed through the sociodrama were conveyed appropriately so that students gained knowledge new, understanding, and getting new experiences. Supported by the results of research that the environment in the school occurs when students adjust to group guidance services. (Hasanah et al., 2015). Based on these supporting journals, it has similarities with researchers, namely using group guidance in providing services to improve student adjustment, while having differences in the techniques used in service delivery. In line with other supporting journals, namely the effect of group guidance services with sociodrama techniques on assertive behavior of students who get the results of an increase in assertive behavior in 10 students after getting treatment, namely group guidance using sociodrama, there is a change in the pretest and posttest categories, namely initially students are in the medium category. being high and group guidance with role playing has an influence on students' assertive behavior (Dewi, 2017). From these supporting journals, there are differences in the variables that the researcher wants to improve but have in common, namely using sociodrama techniques as a tool to improve student attitudes.

"A sign of student success in the adjustment process is the absence of negative emotions in the form of having happiness, facing reality, being confident, and being able to develop one's own abilities" (Fatimah, 2006). The success of this research is expected that grade VIII students will be able to maintain these changes, identify, and develop an attitude of adjustment. It was concluded that group guidance services using sociodrama techniques were considered quite effective in providing material, understanding, helping students who were facing problems, providing solutions to students, making students creative, giving students an overview of alternative solutions in solving problems. Furthermore, group guidance is an activity of providing assistance carried out in groups with the counselor / leader of the BK / counselor with the aim of providing information about material related to science and alternative problem solving alternatives. This understanding is supported by the opinion. According to Gazda (Prayitno \& Anti, 2008) group guidance is an activity carried 
out by counseling teachers by forming groups of 4-12 students with the aim of providing information or helping students.

\section{The Stages in Group Guidance}

The stages of group guidance really need to be done by the group leader. The stages of group guidance activities are early stage, formation stage, transitional stage, activity step, terminating stage (Prayitno \& Anti, 2008). At the early stage, the leader emphasizes more on careful preparation, including forming group memberships in terms of time, place and activities. The next process is greatly helped by systematic preparation. Formation stage which is group members get an understanding of the purpose of the activity, an agreement on the rules and how to carry out activities. Transitional Stage which is group members are ready to proceed to the activity stage. If there is still unrest or tension in each group member, the group leader will do another ice breaking to break the ice. Activity step namely discussing as a whole, in-depth and thoroughly about the material to be conveyed. It is hoped that group members can develop themselves at this stage, through active discussion between group members to express their opinions as an exercise in developing themselves in communication, ethics in responding to the opinions of others, and as an active listener. Termination stage which is assessment or evaluation which is referred to as the closing stage. At this stage the group has completed the discussion as a whole, in-depth and thoroughly, and group members have found and agreed on alternative solutions to problems. Group members are expected to be able to interpret, develop, and be able to apply them in everyday life, so that group members can identify these topics as preventive or preventive.

In carrying out activities, researchers used the sociodrama stage. The stages contained in sociodrama are starting from preparation to repetition of the game. It has advantages, namely if the results of the evaluation and discussion it is felt that the role playing that has been done is not enough to make students understand the meaning contained, and cannot find a solution from the drama script. So it is obligatory to repeat the sociodrama game with the same material and script.

\section{CONCLUSION}

Based on the results of the research that has been carried out, it can be concluded that sociodrama has an effect on increasing the adjustment of class VIII students after treatment as indicated by theresults posttest that have increased significantly in value. It is proven that the 9 students experienced an increase in the score with the low category increasing to the high category, the moderate category increasing to the high category. It is expected that these students will continue to be consistent with the results they get in the posttest carried out. Therefore, the research hypothesis has been answered and proven by the results obtained, namely 74.11 (results pretest) to 99.78 (results posttest).

\section{ACKNOWLEDGMENT}

The author would like to thank: (1) Dr. Budi Astuti, M.Si as the thesis supervisor (2) Dra. Y. Niken Sasanti, M.Pd as the Principal of SMP Negeri 1 Yogyakarta (3) Arif Suhendarto, S.Pd as the Guidance and Counseling Teacher at SMP Negeri 1 Yogyakarta

\section{REFERENCES}

Ali, Mohammad \& Mohammad Asrori. (2004). Psikologi Remaja Perkembangan Peserta Didik. Jakarta: Bumi Aksara

Blatner, A., Foundations of psychodrama: history, theory, and practice, Springer Publishing Company, New-York, 214-230, (2000) 
Desmita. (2009). Psikologi Perkembangan Peserta Didik. Bandung: PT. Remaja Rosdakarya

Dewi, K. (2017). Pengaruh Layanan Bimbingan Kelompok dengan Teknik Sosiodrama terhadap Perilaku Asertif Siswa. 6(3).

Fatimah, N. (2006). Psikologi Perkembangan Anak dan Remaja. Bandung: Remaja Rosda Karya Offset

Ghufron, M. Nur, Rini Risnawati S. (2010). Teori - Teori Psikologi. Yogyakarta: Ar Ruz Media

Hasanah, A. M. A., Suharso, \& Saraswato, S. (2015). Indonesian Journal of Guidance and Counseling. Indonesian Journal of Guidance and Counseling: Theory and Application, 5(1), 39-44. journal.unnes.ac.id/sju/index.php/jbk

Prayitno \& Erman Anti. (2008). Dasar-Dasar Bimbingan dan Konseling. Jakarta: Rineka Cipta

Romlah, Tatiek. (2006). Teori dan Praktik Bimbingan Kelompok. Malang: Universitas Negeri Malang

Sunarto \& Hartono. (2008). Perkembangan Peserta Didik. Jakarta: Rineka Cipta 